Egyptian Poultry Science Journal

http://www.epsj.journals.ekb.eg/

ISSN: 1110-5623 (Print) - 2090-0570 (Online)

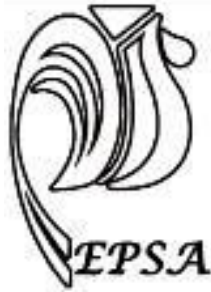

\title{
PHYSIOLOGICAL AND IMMUNOLOGICAL RESPONSES OF DUCKS (CAIRINA MOSCHATA DOMESTICA) TO SILYMARIN SUPPLEMENTATION
}

\section{Asmaa Sh. ELnaggar ${ }^{1}$; Reham, A. M. Ali ${ }^{2}$ and Eman A. El- Said ${ }^{3}$}

1- Dept. of Anim. and Poult.Prod., Fac. of Agric., Damanhour Uni.

2- Dept. of Anim. and Poult. Prod., Fac.of Agric.andNat. Reso.,Aswan Uni.

3- Dept. of Poult. Prod., Fac. of Agric., Damietta Uni.

Corresponding Author: Asmaa Sh. ELnaggar ${ }^{1}$ E-mail:asmaa.elnaggar@agr.dmu.edu.eg

Received: 4/12/2020 Accepted: 20/12/2020

\begin{abstract}
The current study was conducted to investigate the effect of Silymarin extract on productive performance and the immune-physiological status of growing (Cairina Moschata Domestica) ducklings. A total number of 200 - day old ducklings were obtained from a commercial hatchery. Upon arrival they were brooded at $33^{\circ} \mathrm{C}$ for one week and then individually weighed and divided randomly into four treatments of 50 birds in five replicates 10 ducklings each. The first group was served as a control and fed the basal diet without any supplementation, while the second, third and fourth groups were fed the basal diet supplemented with silymarin extract at levels of $0.6,0.9$ or $1.4 \mathrm{~g} / \mathrm{kg}$ dietlevels, respectively. The duration of the experiment was 70 days. Results showed that silymarin at $0.6 \mathrm{~g} / \mathrm{kg}$ diet level positively affected feed conversion ratio, live body weight and body weight gain compared with the control one. Moreover, silymarin recorded highly significant values of globulin fractions $(\alpha, \beta$, and $\gamma$-globulin), immunoglobulins and thyroid hormone concentration. Additionally, silymarin had significantly improved liver functions markers (ALT, AST and ALP) and serum lipid profile and significantly decreased lipid fractions (cholesterol, low density lipoprotein and triglycerides). In a similar way, silymarin induced significant improvement in the antioxidant status including low malondialdehyde (MDA) concentration and higher total antioxidant capacity, glutathione peroxidase and superoxide dismutase enzymes activity. Additionally, pathogenic bacterial counts were significantly reducedgrowth compared with control group.

Conclusion: silymarin extract at $0.6 \mathrm{~g} / \mathrm{kg}$ diet, may be useful for improving growth performance, antioxidant status, liver functions. Notable linear decrease in the serum lipid profile concentration and pathogenic bacteria were observed in treated growing ducks.
\end{abstract}

Key words: silymarin, lipids, immunity, antioxidant, duck. 


\section{INTRODUCTION}

Phytogenic plants are known as a good source of antioxidants. Additionally, they are safe for both living organisms and the environment, but the phytogenic composition may vary widely due to botanical origin, agronomic factors, mode of processing or environment factors (Windisch et al., 2008). Wu et al. (2009) reported that Silybummarianum had been identified as a source of various phytochemicals. Silybum marianum is one of many plants that has been used medicinally as growth enhancers in nutrition (Radko \& Cybulski, 2007 and Andrzejewska et al., 2015) and also inhibits tumor necrosis factor alpha (TNF- $\alpha$ ) induced production of free radicals and lipid peroxidation in cell membranes and modulates T-cell function Mannaet al., 1999 and Nazemian et al., 2010 . The active extract isolated from the seeds of Silybum marianumhas mixture of several flavonolignans isomers called, silymarin, silychristin, silydianin, silybin, and isosilybin (Kummeret al., 2001 and Abenavoli et al., 2010). Pradhan and Girish (2006) and Rajiha (2012) reported that the active component of milk thistle known as silymarin, which represent $4-6 \%$ of the dried seeds or in the aerial parts of milk thistle plant.Silymarin hasdifferent properties like inhibit lipid peroxidation, hopeful complementary medication in diabetes, hepatoprotective activity,antiinflammatoryandanti-cancer activity and acts as an excellent antioxidant (Dixit et al., 2007 and Kshirsagar et al., 2013). Silymarin also led to modulates T-cell function and acts as and acts as scavenging reactive oxygen species (ROS) and thereby protecting cells against ROS(Kshirsagar et al.,2013), via its effect improved the concentrations of the endogenous antioxidant enzymes like superoxide dismutase, glutathione peroxidaseand catalase (Fehér et al., 1988 and Pradhan and Girish 2006), activates antioxidant enzymes that protect DNA from degradation( Kiruthiga etal., 2007), cyclooxygenase and lipoxygenase pathways (Gupta et al., 2000) and inhibited lipid peroxidation, and restricts the regular increasing in blood glucose induced by alloxan (Khazim et al., 2013). Previousreports demonstrated that silymarine had possitive effects on Glycemic control and has got some antidiabetic potential (Maghrani et al., 2004 and Huseini et al., 2006). Silymarin clinically used to amelioration the liver functions like therapy of liver disorders in the chronic, ischemic injury, hepatitis, liver cirrhosis, radiation toxicity and alcoholic liver disease (Saller et al., 2001), detoxification, metabolism of carbohydrates and fats and protein synthesis. In addition, liver is contributory keeping homeostasis within the body (Ward and Daly, 2003). Silymarin has the efficiency to maintain the phagocytic function of avian macrophages (Grizzle et al., 2003) and modify indices of liver functions (Wellington and Jarvis, 2001; Bean, 2002 and Amiridumari et al. 2013). Silymarin improved body weight and feed intake in broilers (Kalorey et al. 2005) and has been shown effective in preventing negative effects on the productive performance of poultry (Tedesco et al.,2004 and Amiridumari et al. 2013). silymarin is effective against all bacterial species, and effectiveness against coliform bacteria (Abed et al., 2015). Despite wide use of silymarin and its active components in conventional and modern medicine, there is not enough information about this material.

Therefore, the current study was designed to evaluate effects of silymarin on productive performance, blood lipid profile, antioxidant status, immune responses, and liver function of growing ducks.

\section{MATERIALS AND METHODS}

\section{- Birds and Management:}

This study was performed in the Poultry Research Unit (El-Bostan Farm), 
Department of Animal and Poultry Production, Faculty of Agriculture, Damanhour University, Damanhour, Egypt, during the period from April to July 2020.

A total of 200 un-sexed - day old ducklings (Cairina Moschata Domestica)were obtained from a commercial hatchery. Upon arrival they were brooded at $33^{\circ} \mathrm{C}$ for one week and then individually weighed and randomly divided into four treatment groups of 50 ducklings in five replicates 10 ducklings each.The initial body weight (BW) of all ducklings was $203 \pm 4.6$ gram at the beginning of the experiment (7 days of age). They were housed in floor pens $\left(1.5^{*} 1.5 \mathrm{~m}\right)$ in a semi-opened room equipped with two exhausted fans to keep normal ventilation and fed ad libitum throughout the whole experiment. The ingredients and nutrient composition of diets fed during starter period (7-35d of age) and grower (36-70d of age)period are shown in Table-1.

The average of silymarin yield was extracted $57.4 \mathrm{mg} / \mathrm{g}$ from milk thistle seeds according to Zheng et al. (2009) and Abou-Zida et al. (2016).Silymarin was added as a powder extract toducks' $\operatorname{diet}(7$ $70 \mathrm{~d}$ of age) as follows.

Groups $1^{\text {st }}, 2^{\text {nd }}, 3^{\text {rd }}$ and $4^{\text {th }}$ were fed basal diets supplemented with silymarin extract at levels of 0.0, 0.6, 0.9 and $1.4 \mathrm{~g} / \mathrm{Kg}$ diet, respectively.

\section{Growth Performance:}

Individual live body weight (LBW, g) of ducks and feed intake (FI, g) were weekly recorded throughout the experimental period (7-70 d of age). Also, body weight gain (BWG, g) and feed conversion ratio (FCR) were calculated for each replicate within treatment groups. Feed conversion ratio was calculated according to the equation: $\mathrm{FCR}=\mathrm{FI}(\mathrm{g}) / \mathrm{BWG}(\mathrm{g})$.

\section{Slaughter traits and blood parameters}

At the end of the experimental period, before blood sample collections, feeders were removed from all ducks for a period of $6 \mathrm{hrs}$. to allow constancy of blood constituents. Five fasted ducks from each treatment at $70 \mathrm{~d}$ of age were randomly taken for slaughter. Blood samples (about 5 $\mathrm{ml}$ ) were collected from each duck into weatherman tubes. Blood samples were centrifuged at $3500 \mathrm{rpm}$ for $20 \mathrm{~min}$ and stored at $-20^{\circ} \mathrm{C}$.

Fasted ducks were individually weighed. After scalding and evisceration carcass and some internal organs (i.e., liver,spleen, thymus gland and abdominal fat) were weighted. Percentage of carcass and organs were calculated based on live body weights. Five serum samples were obtained also from each treatment at $70 \mathrm{~d}$ of age for biochemical analysis using commercial kits. Serum total protein and albumin were measured according to guidelines and recommendation of Grant et al.(1987) and Doumas et al. (1981), respectively. Globulin values were obtained by subtracting albumin values from the corresponding values of total protein, since the fibrinogen usually comprises a negligible fraction (Sturkie, 1986). In addition, biochemical determinations included different types of globulin $(\alpha-$ globulin, $\beta$-globulin and $\gamma$-globulin) according to Bossuyt(2006). Blood glucose was estimated by the glucose oxidase method (Trinder, 1969).Some lipids profile (total cholesterol, triglycerides, high density lipoprotein (HDL-C), low density lipoprotein (LDL-C)) and alkaline phosphatase (ALP) concentrationwere measured according to Stein (1986), Fossati and Prencipe (1982), Lopez-Virella et al.,(1977), Friedewald et al.(1972) and Kind and King (1954). Moreover, serum levels of uricacid and creatinine were also determined using method of Patton and Crouch (1977) and Henry (1974), respectively, besides, the activity of serum aspartate aminotransferase (AST), and serum alanine aminotransferase (ALT), were estimated according to Reitman and Frankel (1957). Serum samples were assigned also for determination of total antioxidant capacity (TAC) according to 
Koracevicet al. (2001), superoxide dismutase (SOD) activity according to Misra and Fridovich (1972), Glutathione (GSH) determined according to (Marzal et al. 2006) and malondialdehyde(MDA) according to the method of Buege (1978).Serum immunoglobulins (IgY, IgM and $\operatorname{IgA}$ ) were determined using ELISA kits according to Bianchi et al.(1995). Triiodothyronine (T3) and thyroxin (T4) were determined in sera using ELISA technique according to Walker (1977) and Wisdom (1976), respectively.

\section{Microbiological examination:}

The contents of the ceca from 5 broiler per treatment group were sampled and pooled according to intestinal segment Ceca content from each segment was immediately transferred under a stream of $\mathrm{CO} 2$ into tubes containing $9 \mathrm{~mL}$ of a sterilized water (El Said, 2017). Total count bacteria were counted on Nutrient Agar. Coliform bacteria on MacConkey agar (MacConkey, 1908), while Lactobacilli SP. were anaerobically assessed on selective agar MRS. (De-MAN et al., 1960)incubated aerobically at $37^{\circ} \mathrm{C}$ for $24 \mathrm{~h}$.

\section{Statistical analysis:}

Data obtained were analyzed using the GLM procedure (Statistical Analysis System (SAS, 2006), using one-way ANOVA using the following model: $\mathrm{Y}_{\mathrm{ik}}=$ $\mu+\mathrm{T}_{\mathrm{i}}+£ \mathrm{fik}$.

Where, $Y_{i k}$ the dependent variable; $\mu$ is the general mean; $T_{i}$ is the effect of experimental treatments; and £ikis the experimental random error. Before analysis,all percentages were subjected to logarithmic transformation $\left(\log 10^{\mathrm{x}}+1\right)$ to normalize data distribution. The differences among means were determined using Duncan's new multiple range test (Duncan, 1955).

\section{RESULTS AND DISCUSSION Growth performance}

As shown in Table (2) the initial body weight (7 days old) was not significantly different among all groups. In addition, live body weight, body weight gain, feed consumption and feed conversion ratio (FCR) of ducklings during growing period interval 7-70 days of age are summarized in Table. 2. The growth performance of ducks was significantly improved by silymarin dietary treatments (p $\leq 0.05)$. Supplementation with silymarin diet significantly increased body weight and weight gain in comparison to control group. Differences in body weight gain due to supplementation were significant, the treated groups of silymarin surpassed the non-treated group in respect of body weight gain by about $13.4,11.7$ and $7.71 \%$, respectively at the 70 days of age. Also, the results for LBW and WG displayed a linear decreased ( $p \leq 0.05)$, as a result of increasing levels of silymarin treatments, with a minimum for the control group ( $p$ $\leq 0.05$ ) during growing period 7-70 days of age. On the other hand, no levels-related effects on feed consumption were observed obtained in the different groups (Table. 2). However, variations were observed for feed conversion ratio among the groups treated $(p \leq 0.05)$. FCR has been observed increased in the low level of silymarin group than the other groups.

Feed consumption of Silymarin groups did not significant effects compare to control group $(\mathrm{P} \leq 0.05)$ during days $7-70$ of age. While, supplementation ofducklings'diets with silymarin significantly improved FCR during the whole experimental period (770) days of age. Throughout the growing period interval (7-70) days of age low concentration of supplementation dietary of silymarin has better effects on LBW, WG and feed conversion ratio than the other groups.

The current results agree with those of (Chand et al., 2011 and Abdalla et al., 2018) who confirmed that supplementation milk thistle plant had positive effect on feed conversion ratio and body weight gain. Silymarin prevent fat accumulation in the liver and increases the elimination of toxins directly from the intestines without absorption in which toxins absorbed from 
the digestive tract first enter the liver resulting in a variety of liver disorders (Karimi et al., 2011). Therefore, silymarin acts as growth promoter and improving productive performance of broiler, particularly body weight gain, feed conversion ratio and immune system (Ershidat, 2017 and Kalorey et al., 2005)and attributed its effects to antioxidant activity in the protein synthesis stimulation by the bird's enzymatic system Gowda and Sastry (2000). In addition, the findings result suggest that silymarin may increase the metabolic rate, improvement in liver function, muscle protein synthesis and protein deposition Noorani et al. (2010).

\section{Carcass characteristics and lymphoid organs:}

Results indicated that the relative weights of carcass significantly increased for the groups supplied with different levels of silymarin compared with control treatment (Table 3). Moreover, the group supplied with low level of Silymarin significantly increased relative weight of carcass compared with the other treated groups. On the other hand, supplementation with different levels of silymarin haddecreased significanteffectson relativeweight of abdominal fat. Nevertheless, all supplementations had no significant effects on the relative weightof thymus,spleen and liver organs. Abdalla et al., 2018 illustrated that, milk thistle plant supplementation diets had no significant effects on relative weight of thymus and abdominal fat.This is may refer to that silymarin retains water in the cytoplasm of hepatocytes conducive to enlargement of liver cells, fulfilling in raising total liver mass and volume, this is compatible with results which obtained by (Noorani et al., 2010).

\section{Blood Traits}

Table.4.Reports the results for triglycerides, total cholesterol, high- and low-density lipoprotein (HDL and LDL) levels were positively affected by the dietary treatment compare to control group.
Lipids profile (TG, Chol. and LDL) displayed a linear decrease $(\mathrm{p} \leq 0.05)$, as a result of increasing dietary levels of silymarin, with a maximum for the control group $(p \leq 0.05)$. Despite, a linear increase in the HDL values $(\mathrm{p} \leq 0.05)$ was identified. These results are in accordance to Abdalla et al., 2018 who reported that supplementing diet with milk thistle plant has positive effects on activity of total lipids, triglycerides cholesterol, and LDL significantly decreased, however, HDL significantly increased compared with control group.The addition of silymarin treatments show significant decrease of serum total cholesterol and triglyceride levels, this may attribute to unsaturated fatty acids in the levels of silymarin, which may stimulate cholesterol secretion into the intestine, and the oxidation of cholesterol to bile acids. Silymarin is used in helpful therapy of liver diseases and its cytoprotective activity is believed to be based on antioxidant properties. Škottová et al. (1999) reported that silymarin inhibites the dietary induced hypercholesterolemia in rats (Krečman et al., 1998), significantly decrease the lipid profiles and LDL levels in vitro.

Moreover, serum liver and renal function parameters reported in (Table 4). The parameters associated with the renal function wasn't influenced by silymarin treatments. No significant changes in the levels of creatinine and uric acid values were observed.

These results are in line with what has been reported by Talebi et al., 2015 who reported that creatinine values were not significant among values of the groups.

Despite, the parameters associated with the liver functions, including ALK. P, ALT and AST were showed a linear decrease significant effects for all treated groups compare to control one ( $\mathrm{p} \leq 0.05$ ), which was in agreement with findings of Neshatgharamaleki and Mohajeri (2014). Dietary levels of silymarin were reported to protect the liver induced hepatic injury 
through its potent antioxidant activity in vivo. The addition of silymarin may improve the liver functions (AST, ALT and ALP) were significantly decreased, these results indicate that treating with silymarin did not have any adverse effect on the function of kidney and liver. In this respect, El-Gazayerly et al., 2014 noted that the liver enzymes activities were significantly decreased in female rats exposed to silymarin drug. Silymarin had beneficial effects and improves indices of liver function(Wellington \& Jarvis, 2001, Huseini et al., 2006, Pradhan and Girish, 2006 and Jose et al., 2011 and Talebi et al., 2015) and kidney cells, where it aids in repair and regeneration by increasing protein and nucleic acid synthesis ( Kaur et al., 2010). Previously reported which decreased the levels of ALT, AST and ALP levels after treatment with silymarin. Similarly, Simanek et al. (2000), Shaker et al. (2010) and Abdalla et al., 2018 who reported that supplementing diet with milk thistle plant significantly improved the liver function and, since the activity of AST, ALT and ALP significantly decreased compared with control group. In addition, Shaker et al. (2010) and Bhattacharya (2011) indicated that silymarin used for relieving the liver diseases and its mechanism of action mainly as anticarcinogenic and antiradical that may be due to decrease in liver enzyme levels. Moreover, silymarin shows an improvement in serum liver enzymatic levels and strong antioxidant that has been reduce blood cholesterol and enhance liver cell regeneration. Moreover, Silymarin may be decreasing cholesterol and phospholipids, may be in part due to decreased liver cholesterol synthesis.

Liver is the key organ which leads various physiological functions in Poultry. The nutritional state of birds is not only determined by what they feed, but also depends on the function and status of the liver and it plays a physiology function of poultry (Saeed et al., 2017a\&b). The ingested toxins absorbed from the guts, firstly enter the liver and can accumulate, resulting in disease (Shaker et al., 2010). Although the mechanism of action silymarin still unclear, silymarin has been reported to have antioxidant activity, antifibrotic and antiviral properties to combat such problems (Karimi et al., 2011). Silymarin has fast conjugation in the liver and is primarily secreted in bile to control hepatic inflammation in vivo (Morishima et al., 2010). No levels-related effects on total protein and albumin were observed in blood serum obtained from the different groups (Table 5). However, variations were observed for globulin, $\alpha-$ globulin, $\beta$-globulin and $\gamma$-globulin concentrations among the groups $(\mathrm{p} \leq 0.05)$. Moreover, globulin, $\alpha-$ globulin and $\gamma$ globulin levels displayed a linear decrease $(\mathrm{p} \leq 0.05)$, as a result of increasing levels of dietary silymarin (Table 5).

These results are in line with Abdalla et al. (2018) and Lutsenko et al. (2008) who stated that diet supplied with silymarin significantly increased total protein, albumin and globulin compared with control group.

The results in Table 5. related for humoral immune response of ducks showed significant increases in immunoglobulin $G$ in silymarin groups compared with control group. The results for the serum immunoglobulins' $\mathrm{G}$ (IgM and $\operatorname{Ig} \mathrm{A}$ ) were unaffected by dietary treatments, however, a linear increase in IgG levels was noticed by silymarin treatments. IgG showed a linear decrease because of the increasing dietary inclusion silymarin, with a minimum for control group $(p \leq 0.05)$. Mojahedtalab et al. (2013) reported that Silymarin improved productive performance and increased humoral immunity in broilers and increased IgG titer in treated groups compared to control group $(\mathrm{P} \leq 0.05)$. Previous studies have shown that silymarin has different immunomodulatory activities and has antiinflammatory effects. As an immunomodulator agent, silymarin inhibits 
T-lymphocyte function at low doses while stimulates inflammatory processes at high doses (Wilasrusmee et al., 2002 and Esmaeil et al., 2017). Also, Wilasrusmee et al., 2002 showed that silymarin has helpful immunostimulatory effects of increasing the immunity to infectious diseases.

As reported in Table 6. thyroxin and triiodo thyronine were partially influenced by the dietary supplementation, moreover, concerning T3/T4 ratio, results in Table 6. Showed that silymarin improved $\mathrm{T} 4$ conversion to T3 hormone. This result suggests that silymarin facilitated the conversion of $\mathrm{T} 4$ to $\mathrm{T} 3$. In special, the hepatic enzyme is importantly thought that participate to peripheral $\mathrm{T} 3$ production and in addition to the bioactivation of $\mathrm{T} 4$ to $\mathrm{T} 3$ (Robin et al., 2000).Kummer et al., 2001 reported that silymarin increased the serum concentrations of thyroid hormones. This study showed effects of silymarin on increasing oxidative metabolism of steroid hormones in hepatic tissue and demonstrated modulation of metabolizing enzymes. This attributed the stimulatory effects of silybin, which is the principal component of silymarin on ribosomal RNA and DNA synthesis resulting from direct interaction with RNA-polymerase were demonstrated repeatedly (Fraschini et al., 2002 Kummer et al., 2001).

Data in Table (6) revealed a significant $(\mathrm{P} \leq 0.05)$ decrease in serum glucose concentration in treated groups compared with the control diet. In this respect, (Talebi et al., 2015 and Huseini et al., 2006) have reported that silymarin had a beneficial effect on improving the glycemic profile improved the glycemic control system in diabetic. The hypoglycemic of silymarin may be due its antioxidant activity by reducing insulin resistance (Soto et al. 2004 and Jose et al., 2011). Silymarin promoted repair and renovation of the pancreatic tissue, protecting pancreatic tissue against damaging elements, thereby hypoglycaemic effect are among mechanisms pointed out for silymarin beneficial effects on health and productive performance of quail (Soto et al. 2003; Behboodi et al. 2017).

The antioxidant enzymes activities were influenced by silymarin treatments as reported in table. 6.Results revealed that silymarin supplementation to silymarin treatments ducks' significantly increased TAC in duck's serum compare with control group but, better response was for ducks fed $0.6 \mathrm{~g} / \mathrm{kg}$ silymarin/diet than other groups. Similarly, MDA significantly decreased by adding silymarin. Moreover, TAC, GPX, GSH and SOD values were remained constant between silymarin groups, which, showed a linear decrease with increasing dietary levels of silymarin ( $\mathrm{p} \leq 0.05)$. Treated groups produced an antioxidant activity as evident by reducing lipid peroxidation byproduct (MDA), restoring activities of TAC and SOD enzymesand increasing of glutathione activity. Moreover, previous studies have attributed the protective effects of silymarin to antifibiotic effects (Jia et al. 2001), free radical scavenging capacity (Saller et al. 2001) and enhance glutathione activity in peripheral blood cells (Par et al. 2000, Lucena et al. 2002), improvement the activity of catalase and super oxide dismutase levels (Lee et al., 2003 and Fanoudi et al., 2020) and significantly diminishing malondialdehyde levels (Brown et al., 2004 and Draz et al. 2015). The adverse relation between HDL- chol and MDA attributed a synergetic effect of both, where, HDL has a preventative function in protecting from atherosclerosis, while, MDA activity acts as a reliable indicator of antioxidant activity. These results agree with (Bhattacharya, 2011 and Kshirsagar et al., 2013) who reported that silymarin has been act as an effective antioxidant and preventing free radicals reactive oxygen species (ROS) generating enzymes, which scavenges excessive (O2-) thus reducing and preventing its harmful effect to cells in addition to inducing lipid peroxidation in vivo( El-Far et al., 2009 
a\&b). Silymarin maintains an optimal equilibrium in the cell by activating a range of enzymatic and non-enzymatic antioxidant defense systems of cells involving restore and augment antioxidant status by significantly enhancing gene expression of antioxidant enzymes (Upadhyay et al., 2010; Surai, 2015; Tan et al., 2015; Zhao et al., 2015 El-Far et al., 2018).

The populations of total viable bacterial count (cfu x 10\% sample), lactobacillus and E. coli of cecal contents (cfu x 10\% $/ \mathrm{g}$ sample), were affected by silymarin dietary supplementation (Table 7). The results revealed that silymarin supplementation significantly decreased count of total bacteria and coliform bacteria compared with control treatment. which had more effective on decreasing intestinal total count and count of coliform bacteria. It is likewise believed that silymarin supplementation displayed significant decrease $(p \leq 0.05)$ total bacterial count, as a result of increasing lactobacillus $S p$., while E. coli showed a linear decreased (p $\leq 0.05$ ). Silymarin supplementation has enhanced positive effects on growth performance, controlling and inhibition of growth of pathogenic microorganism.However, dietary supplementation significantly increased count of Lactobacillus Sp. bacteria. The results revealed that the highest lactobacillus bacterial count was recorded to dietary's silymarin. groups. Silymarin has enhanced effects of benefit bacteria in the large intestinal tract and improve the production of lactic acid and may provide an energy source of intestinal epithelial cell growth that improves nutrient absorption in duck intestine.Bajwa et al., 2016 showed that silymarin was showed minimal activity against resistant E. coli and good activity against total bacteria. silymarin has been used as anti-carcinogenic because of their cytotoxic activity. So, these phytochemicals may also be toxic to bacterial cell and may be responsible for the antibacterial activity. This in agreement with Abed et al., 2015 and Lahlah et al., 2012, who observed that silymarin was effective against all bacterial species, however, its effectiveness against Escherichia coli was higher than others. The antibacterial activity of flavonoids can be explained by the toxicity of this component towards nonspecific interactions in showed susceptibility, such as the establishment of hydrogen bonds with the cell walls proteins or enzymes, the chelation of metal ions, inhibition of bacterial metabolism, sequestration of substances necessary for the growth of bacteria. Also, the $\beta$ ring of flavonoids is important in the intercalation with nucleic acids, thus inhibits DNA and RNA synthesis. It can also inhibit the DNA gyrase of Escherichia coli(Lee et al., 2003 and Bessam and Mehdadi, 2014). The microbes serve a number of important functions including energy extraction from food through a variety of mechanisms through effect both sides of the energy balance equation that monitoring and control of energy consumption and storage, digests plant polysaccharides and complex carbohydrates (Davis, 2017). In addition, the gut microbes can metabolize short chain fatty acids, producing vitamins such as biotin, folate and vitamin $\mathrm{K}$; preventing colonization by pathogens; and assisting in the development of immune system (Clarke et al., 2012).

\section{CONCLUSION}

Generally,itcanberecommendedthat silymarin extract at $0.6 \mathrm{~g} / \mathrm{kg}$ diet has enhanced positive effects on growth performance, enhanced antioxidant enzymes andimproved immuneresponses and liver functions.Moreover, silymarin extractsignificantly decreasedcount of pathogenic bacteria of growing ducks (CAIRINA MOSCHATA DOMESTICA). 


\section{ACKNOWLEDGMENTS}

The authors gratefully acknowledge Prof.

Dr. Ibrahim Elwardany Emeritus

Professor of poultry Physiology , Faculty of Agriculture, Ain Shams University, for his great help, advice and giving our support in completing this work

Table (1):Composition and calculated analysis of the basal diets:

\begin{tabular}{|l|c|c|}
\hline Ingredients (\%) & $\begin{array}{c}\text { Starter } \\
\text { ( 7-35 d) }\end{array}$ & $\begin{array}{c}\text { Grower } \\
\text { ( 36- 70d ) }\end{array}$ \\
\hline Yellow corn & 56.80 & 68.70 \\
Soybean meal (44\%) & 38.00 & 26.00 \\
Limestone & 1.00 & 1.05 \\
Dicalcium phosphate & 1.90 & 1.95 \\
Salt (NaCl) & 0.30 & 0.30 \\
Vit+Min.premix 1 & 0.30 & 0.30 \\
DL-Methionine & 0.11 & 0.15 \\
Sunflower oil & 1.50 & 1.50 \\
Antifungal & 0.09 & 0.95 \\
Total & 100.0 & 100.0 \\
\hline Calculated analysis (NRC, 1994) & \\
\hline ME,kcal/Kg & 2884 & 2999 \\
Crude protein, \% & 21.6 & 17.34 \\
Crude fiber, \% & 3.92 & 3.37 \\
Ether extract, \% & 3.95 & 4.30 \\
Lysine, \% & 0.90 \\
Methionine \% & 1.18 & 0.39 \\
Meth. + Cyst., \% & 0.44 & 0.69 \\
Calcium, \% & 0.79 & 1.60 \\
Total phosphorus, \% & 0.92 & 0.47 \\
Available phosphorus\% & 0.78 & 0.31 \\
\hline
\end{tabular}

${ }^{1}$ Vit+Min mix. /Kg diet Vit. A: 6000 IU, Vit. D3: 2000 ICU, vit. E (dl- $\alpha$-tocopheryl acetate: 10 IU, , calcium pantothenate: $10 \mathrm{mg}$, menadione: $2.5 \mathrm{mg}$, nicotinic acid: $12 \mathrm{mg}$, thiamine: $3 \mathrm{mg}$, vit. $\mathrm{B}_{12}$ : $4 \mu \mathrm{g}$, vit. $\mathrm{B}_{6}: 5 \mathrm{mg}$, riboflavin: $2.5 \mathrm{mg}$, Choline chloride: $300 \mathrm{mg}$, folic acid: $0.50 \mathrm{mg}$ and biotin: $0.02 \mathrm{mg}$. Trace mineral (mg/ kg of diet: Fe: $35 \mathrm{mg}$, , Mn: $80 \mathrm{mg}$, Cu: $8 \mathrm{mg}$ Se: $0.1 \mathrm{mg}$ and Zn: 60 $\mathrm{mg}$ ). 
Asmaa Sh. ELnaggar ${ }^{1}$ et al.

Table (2): Effect of different levels of silymarin on growth performanceof growing ducks.

\begin{tabular}{|c|c|c|c|c|c|c|}
\hline Items & Control & $\begin{array}{r}\text { Silymarin } \\
0.6 \mathrm{~g} \\
\end{array}$ & $\begin{array}{r}\text { Silymarin } \\
0.9 \mathrm{~g}\end{array}$ & $\begin{array}{r}\text { Silymarin } \\
1.4 \mathrm{~g}\end{array}$ & SEM & P-Value \\
\hline \multicolumn{7}{|c|}{ Live body weight (g) } \\
\hline $7 \mathrm{~d}$ & 206 & 201 & 200 & 205 & 4.60 & 0.748 \\
\hline $35 d$ & $1250^{\mathrm{b}}$ & $1561^{\mathrm{a}}$ & $1552^{\mathrm{a}}$ & $1400^{\mathrm{ab}}$ & 74.89 & 0.030 \\
\hline $70 d$ & $3204^{b}$ & $3600^{\mathrm{a}}$ & $3550^{\mathrm{a}}$ & $3434^{\mathrm{ab}}$ & 86.69 & 0.024 \\
\hline \multicolumn{7}{|c|}{ Body weight gain (g) } \\
\hline $7-35 \mathrm{~d}$ & $1044^{b}$ & $1360^{\mathrm{a}}$ & $1352^{\mathrm{a}}$ & $1195^{\mathrm{ab}}$ & 75.08 & 0.027 \\
\hline 36-70d & 1954 & 2039 & 1998 & 2034 & 81.78 & 0.873 \\
\hline $7-70 \mathrm{~d}$ & $2998^{b}$ & $3399^{\mathrm{a}}$ & $3350^{\mathrm{a}}$ & $3229^{\mathrm{ab}}$ & 87.17 & 0.023 \\
\hline \multicolumn{7}{|c|}{ Feed consumption $(\mathrm{g})$ : } \\
\hline $7-35 d$ & 3111 & 3090 & 3108 & 3094 & 181.40 & 0.990 \\
\hline 36-70d & 7010 & 6690 & 6790 & 6860 & 230.01 & 0.798 \\
\hline $7-70 \mathrm{~d}$ & 10121 & 9780 & 9898 & 9954 & 307.52 & 0.887 \\
\hline \multicolumn{7}{|c|}{ Feed conversion ratio (g feed/g gain). } \\
\hline $7-35 d$ & $2.98^{\mathrm{a}}$ & $2.27^{\mathrm{c}}$ & $2.30^{\mathrm{c}}$ & $2.59^{\mathrm{b}}$ & 0.025 & 0.001 \\
\hline $36-70 d$ & $3.59^{\mathrm{a}}$ & $3.29^{\mathrm{b}}$ & $3.40^{\mathrm{ab}}$ & $3.37^{\mathrm{ab}}$ & 0.077 & 0.056 \\
\hline $7-70$ & $3.38^{\mathrm{a}}$ & $2.88^{\mathrm{c}}$ & $2.95^{\mathrm{c}}$ & $3.08^{\mathrm{b}}$ & 0.040 & 0.001 \\
\hline
\end{tabular}

Table (3): Effect of different levels of silymarin on carcass characteristics and some lymphoid organs of growing ducks.

\begin{tabular}{|l|c|c|c|c|c|c|}
\hline \multicolumn{1}{|c|}{ Items } & Control & $\begin{array}{c}\text { Silymarin } \\
\mathbf{0 . 6 g}\end{array}$ & $\begin{array}{c}\text { Silymarin } \\
\mathbf{0 . 9 g}\end{array}$ & $\begin{array}{c}\text { Silymarin } \\
\mathbf{1 . 4 g}\end{array}$ & SEM & P-Value \\
\hline Carcass characteristics $(\%)$ \\
\hline carcass yield \% & $66.84^{\mathrm{c}}$ & $71.51^{\mathrm{a}}$ & $70.91^{\mathrm{ab}}$ & $68.32^{\mathrm{bc}}$ & 0.91 & 0.007 \\
Liver \% & 2.22 & 2.34 & 2.18 & 2.22 & 0.06 & 0.26 \\
Abdominal Fat \% & $1.00^{\mathrm{a}}$ & $0.76^{\mathrm{b}}$ & $0.85^{\mathrm{b}}$ & $0.85^{\mathrm{b}}$ & 0.03 & 0.001 \\
\hline \multicolumn{7}{|l|}{} \\
\hline Lymphoid organs (\%) \\
Spleen \% & 0.277 & 0.313 & 0.284 & 0.282 & 0.013 & 0.22 \\
Thymus \% & 0.126 & 0.131 & 0.123 & 0.125 & 0.001 & 0.40 \\
\hline
\end{tabular}

${ }^{\mathrm{a}, \mathrm{b}, \mathrm{c}}$ Means in the same row followed by different superscripts are significantly different at $(\mathrm{p} \leq 0.05)$; $\mathrm{SEM}=$ Standard error of means. 
silymarin, lipids, immunity, antioxidant, duck

Table(4): Effect of different levels of silymarin on serum lipids concentration, liver and kidney functionof growing ducks

\begin{tabular}{|l|c|c|c|c|c|c|}
\hline \multicolumn{1}{|c|}{ Items } & Control & $\begin{array}{c}\text { Silymarin } \\
\mathbf{0 . 6 g}\end{array}$ & $\begin{array}{c}\text { Silymarin } \\
\mathbf{0 . 9 g}\end{array}$ & $\begin{array}{c}\text { Silymarin } \\
\mathbf{1 . 4 g}\end{array}$ & SEM & P-Value \\
\hline TG, (mg/dl) & $120.6^{\mathrm{a}}$ & $98.2^{\mathrm{b}}$ & $95.0^{\mathrm{b}}$ & $87.2^{\mathrm{b}}$ & 5.69 & 0.0049 \\
Chol., (mg/dl) & $200.9^{\mathrm{a}}$ & $166.9^{\mathrm{b}}$ & $164.9^{\mathrm{b}}$ & $160.8^{\mathrm{b}}$ & 7.40 & 0.0051 \\
HDL, (mg/dl) & $49.0^{\mathrm{c}}$ & $60.5^{\mathrm{a}}$ & $56.1^{\mathrm{ab}}$ & $54.1^{\mathrm{b}}$ & 1.68 & 0.0017 \\
LDL, (mg/dl) & $127.7^{\mathrm{a}}$ & $86.7^{\mathrm{b}}$ & $89.8^{\mathrm{b}}$ & $89.2^{\mathrm{b}}$ & 4.79 & 0.001 \\
Uric, (mg/dl) & 3.47 & 3.39 & 3.46 & 3.50 & 0.05 & 0.532 \\
Creatinine, (mg/dl) & 0.37 & 0.34 & 0.37 & 0.39 & 0.05 & 0.934 \\
AST, (U/L) & $61.45^{\mathrm{a}}$ & $55.29^{\mathrm{b}}$ & $54.90^{\mathrm{b}}$ & $53.40^{\mathrm{b}}$ & 1.54 & 0.0026 \\
ALT, (U/L) & $31.10^{\mathrm{a}}$ & $24.92^{\mathrm{b}}$ & $24.08^{\mathrm{b}}$ & $23.38^{\mathrm{b}}$ & 1.79 & 0.0283 \\
Alk. P,(U/100ml) & $17.95^{\mathrm{a}}$ & $12.80^{\mathrm{b}}$ & $11.58^{\mathrm{b}}$ & $11.67^{\mathrm{b}}$ & 0.93 & 0.0013 \\
\hline
\end{tabular}

${ }^{\mathrm{a}, \mathrm{b}, \mathrm{c}}$ Means in the same row followed by different superscripts are significantly different $a t(p \leq 0.05)$; $\mathrm{SEM}=$ Standard error of means, Chol.= total cholesterol; $\mathrm{TG}=$ triglycerides; HDL=high-density lipoprotein; $\mathrm{LDL}=$ low-density lipoprotein, $\mathrm{AST}=$ aspartate amino transferase; ALT=alanine amino transferase; Alk. $\mathrm{P}=$ Alkaline phosphatase

Table(5): Effect of different levels of silymarin on serum protein fraction and immunoglobulins of growing ducks

\begin{tabular}{|l|c|c|c|c|c|c|}
\hline \multicolumn{1}{|c|}{ Items } & Control & $\begin{array}{c}\text { Silymarin } \\
\mathbf{0 . 6 g}\end{array}$ & $\begin{array}{c}\text { Silymarin } \\
\mathbf{0 . 9 g}\end{array}$ & $\begin{array}{c}\text { Silymarin } \\
\mathbf{1 . 4 g}\end{array}$ & SEM & P-Value \\
\hline Total protein (g/dl) & 5.87 & 5.97 & 5.96 & 5.97 & 0.04 & 0.193 \\
Albumin, (g/dl) & 3.10 & 3.01 & 3.04 & 3.06 & 0.04 & 0.277 \\
Globulin (g/dl) & $2.77^{\mathrm{b}}$ & $2.97^{\mathrm{a}}$ & $2.92^{\mathrm{a}}$ & $2.90^{\mathrm{a}}$ & 0.03 & 0.003 \\
Albumin/globulin & $1.12^{\mathrm{a}}$ & $1.01^{\mathrm{b}}$ & $1.04^{\mathrm{b}}$ & $1.06^{\mathrm{ab}}$ & 0.02 & 0.013 \\
$\alpha-$ globulin, (mg/ml) & $56.20^{\mathrm{c}}$ & $67.05^{\mathrm{a}}$ & $66.78^{\mathrm{a}}$ & $62.07^{\mathrm{b}}$ & 0.76 & 0.0027 \\
$\beta$-globulin $(\mathrm{mg} / \mathrm{ml})$ & $85.64^{\mathrm{b}}$ & $96.20^{\mathrm{a}}$ & $95.81^{\mathrm{a}}$ & $93.11^{\mathrm{a}}$ & 1.12 & 0.0014 \\
$\gamma$-globulin, (mg/ml) & $115.09^{\mathrm{b}}$ & $128.27^{\mathrm{a}}$ & $127.75^{\mathrm{a}}$ & $124.14^{\mathrm{a}}$ & 1.50 & 0.001 \\
IgA, (mg/100 ml) & 72.9 & 74.6 & 78.9 & 79.9 & 0.987 & 0.098 \\
IgM, (mg/100 ml) & $221^{\mathrm{b}}$ & $260^{\mathrm{a}}$ & $276^{\mathrm{a}}$ & $276^{\mathrm{a}}$ & 2.45 & 0.001 \\
IgG, (mg/100 ml) & $958^{\mathrm{b}}$ & $997^{\mathrm{a}}$ & $988^{\mathrm{a}}$ & $995^{\mathrm{a}}$ & 9.77 & 0.002 \\
\hline
\end{tabular}

${ }^{\mathrm{a}, \mathrm{b}, \mathrm{c}}$ Means in the same row followed by different superscripts are significantly different at $(\mathrm{p} \leq 0.05)$; $\mathrm{SEM}=$ Standard error of means, IgA= Immunoglobulin A; IgG= Immunoglobulin $\mathrm{G}$; $\mathrm{IgM}=$ Immunoglobulin M. 
Asmaa Sh. ELnaggar ${ }^{1}$ et al.

Table (6): Effect of different levels of silymarinon thyroid hormones, glucose and antioxidant status of growing ducks.

\begin{tabular}{|l|l|l|l|l|l|l|}
\hline Items & Control & $\begin{array}{r}\text { Silymarin } \\
0.6 \mathrm{~g}\end{array}$ & $\begin{array}{r}\text { Silymarin } \\
0.9 \mathrm{~g}\end{array}$ & $\begin{array}{r}\text { Silymarin } \\
1.4 \mathrm{~g}\end{array}$ & \multicolumn{1}{|c|}{ SEM } & $\begin{array}{c}\text { P- } \\
\text { Value }\end{array}$ \\
\hline T3, (ng/ml) & $3.23^{\mathrm{c}}$ & $5.47^{\mathrm{a}}$ & $5.08^{\mathrm{b}}$ & $4.86^{\mathrm{b}}$ & 0.12 & 0.002 \\
$\mathrm{~T} 4,(\mathrm{ng} / \mathrm{ml})$ & $16.84^{\mathrm{b}}$ & $21.04^{\mathrm{a}}$ & $19.11^{\mathrm{ab}}$ & $18.70^{\mathrm{ab}}$ & 0.94 & 0.044 \\
T3/T4 ratio & $0.194^{\mathrm{b}}$ & $0.261^{\mathrm{a}}$ & $0.272^{\mathrm{a}}$ & $0.262^{\mathrm{a}}$ & 0.02 & 0.010 \\
Glucose (mg/dl) & $198.4^{\mathrm{a}}$ & $192.4^{\mathrm{ab}}$ & $181.2^{\mathrm{b}}$ & $187.4^{\mathrm{ab}}$ & 4.23 & 0.063 \\
TAC, $(\mathrm{mmol} / \mathrm{L})$ & $1.32^{\mathrm{b}}$ & $1.78^{\mathrm{a}}$ & $1.65^{\mathrm{ab}}$ & $1.66^{\mathrm{ab}}$ & 0.12 & 0.083 \\
GPX $(\mathrm{U} / \mathrm{L} / \mathrm{h})$ & $0.218^{\mathrm{b}}$ & $0.414^{\mathrm{a}}$ & $0.372^{\mathrm{ab}}$ & $0.356^{\mathrm{ab}}$ & 0.05 & 0.069 \\
GSH (mg/ml) & $920^{\mathrm{b}}$ & $985^{\mathrm{a}}$ & $977^{\mathrm{a}}$ & $977^{\mathrm{a}}$ & 16.95 & 0.052 \\
SOD $(\mathrm{U} / \mathrm{ml})$ & $232.8^{\mathrm{b}}$ & $269.8^{\mathrm{a}}$ & $270.0^{\mathrm{a}}$ & $281.0^{\mathrm{a}}$ & 9.46 & 0.013 \\
MAD $(\mathrm{pmol} / \mathrm{ml})$ & $164.7^{\mathrm{a}}$ & $133.0^{\mathrm{b}}$ & $138.4^{\mathrm{b}}$ & $137.1^{\mathrm{b}}$ & 8.16 & 0.054 \\
\hline
\end{tabular}

${ }_{\mathrm{a}, \mathrm{b}, \mathrm{c}}$ Means in the same row followed by different superscripts are significantly different at $(\mathrm{p} \leq 0.05)$; $\mathrm{SEM}=$ Standard error of means. T3= triiodothyronine; T4=thyroxine, TAC=total antioxidant capacity; GPX =glutathione peroxidase; $\mathrm{GSH}=$ glutathione; $\mathrm{SOD}=$ superoxide dismutase, MAD= malondialdehyde

Table (7): Effect of different levels of silymarin on Bacterial counts of growing ducks

\begin{tabular}{|c|c|c|c|c|c|c|}
\hline Items & Control & $\begin{array}{r}\text { Silymarin } \\
0.6 \mathrm{~g}\end{array}$ & $\begin{array}{r}\text { Silymarin } \\
0.9 \mathrm{~g}\end{array}$ & $\begin{array}{r}\text { Silymarin } \\
1.4 \mathrm{~g}\end{array}$ & SEM & $\begin{array}{c}\text { P- } \\
\text { Value }\end{array}$ \\
\hline TBC $\left(\mathrm{cfu} \times 10^{6}\right)$ & $244.0^{\mathrm{a}}$ & $180.8^{\mathrm{b}}$ & $183.8^{\mathrm{b}}$ & $181.6^{\mathrm{b}}$ & 11.38 & 0.003 \\
\hline Lactobacillus Sp. (cfu x $\left.10^{3}\right)$ & $105.0^{\mathrm{b}}$ & $168.8^{\mathrm{a}}$ & $168.8^{\mathrm{a}}$ & $164.2^{\mathrm{a}}$ & 13.14 & 0.008 \\
\hline E.Coli $\left(\mathrm{cfu} \times 10^{3}\right)$ & $153.4^{\mathrm{a}}$ & $94.4^{\mathrm{b}}$ & $102.0^{\mathrm{b}}$ & $100.4^{\mathrm{b}}$ & 9.14 & 0.001 \\
\hline
\end{tabular}

${ }^{a, b}$ Means in the same row followed by different superscripts are significantly different at $(\mathrm{p} \leq 0.05)$; $\mathrm{SEM}=$ Standard error of means. $\mathrm{TBC}$

$=$ Total Bacterial Count 


\section{REFERENCES}

Abdalla, A.; Abou-Shehema, B. M.; Hamed, R. S. and El-deken, M. R., 2018. Effect of Silymarin Supplementation on The Performance of Developed Chickens Under Summer Conditions 1-During Growth Period. Egypt. Poult. Sci., 38, (I):305-329.

Abed, I. J.; Al-Moula, R. and Abdulhasan, G. A., 2015. Antibacterial Effect of Flavonoids Extracted from Seeds of Silybum marianum against Common Pathogenic Bacteria. World J. Exp. Biosci., 3: 36-39.

Abenavoli, L.; Capasso, R.; Milic, N. and Capasso, F., 2010. Milk thistle in liver diseases: past, present, future. Phytother. Res., 24: 1423-1432. https://doi.org/10.1002/ptr.3207

AbouZid, S. F.; Chen, S. N.; McAlpine, J. B.; Friesen, J. B. and Pauli, G. F., 2016. Silybum marianum pericarp yields enhanced silymarin products. Fitoterapia, 112: 136-143.

Amiridumari, H.; Sarir, H.; Afzali, N. and Fanimakki, O., 2013. Effects of milk thistle seed against aflatoxin B1 in broiler model. J. Res. Med. Sci., 18:786-790.

Andrzejewska, J.; Martinelli, T. and Sadowska, K., 2015. Silybum marianum: non-medical exploitation of the species. Ann. Appl. Biol., 167:285297 doi:10.1111/aab.12232.

Bajwa, A.; Tariq, S.; Yuchi, A.; Hafeez, R.; Arshad, A.; Zaman, M.; Aqeel, T. andMushtaq, M. N., 2016. Evaluation of Anti-bacterial Activity of Silybum marianum against Pathogenic and Resistant Bacteria, European Journal of Medicinal Plants13(4): 1-7.

Jia, J.; Bauer, M.; Cho, J. J.; Ruehl, M.; Milani, S.;Boigk, G.; Riecken, E. O.; Schuppan, D., 2001. Antifibrotic effect of silymarin in rat secondary biliary fibrosis is mediated by downregulation of procollagen alpha1(I) and TIMP-1. Journal of Hepatology, 35 (3): 392-398.
DOI:https://doi.org/10.1016/S01688278(01)00148-9

Bean, P. 2002. The use of alternative medicine in the treatment of hepatitis $\mathrm{C}$. Am. Clin. Lab. 21(4):19-21.

Behboodi, H. R.; Samadi, F.; Shargm,S. M.; Ganji,F. and Samadi, S., 2017. Effects of silymarin on growth performance, internal organs and some blood parameters in Japanese quail subjected to oxidative stress induced by carbon tetrachloride. Poult Sci J. 1:3140.

Bessam, F. H. and Mehdadi Z., 2014. Evaluation of the Antibacterial and Antifongigal Activity of different extract of Flavonoïques Silybum marianum L. Adv. Environ. Biol.8: 1-9.

Bhattacharya, S., 2011. Milk thistle (Silybum marianum L. Gaert.) seeds in health. In: Preedy V.R., Watson R.R., Patel V. Editors. Nuts and Seeds in Health and Disease Prevention. 1st Ed., London, Burlington, San Diego: Academic Press (an imprint of Elsevier).

Bianchi, A. T. J.; Moonen-Leusen, H. W. M.; Heijden, P. J. and Bokhout, B. A., 1995. The use of a double antibody sand-wich ELISA and monoclonal antibodies for the assessmentof porcine $\operatorname{IgM}$, IgG, and $\operatorname{Ig} A$ concentrations. Vet. Immunol. Immunopathol., 44:309-317.

Bossuyt, X., 2006. Advances in serum protein electrophoresis. Adv. Clin. Chem., 42: 43-80

Brown, L. A.; Harris, F. L.; Ping, X. D.; Gauthier, T. W., 2004. Chronic ethanol ingestion and the risk of acute lung injury: a role for glutathione availability. Review, Alcoho., 133(3): 191-197.DOI: 10.1016/j.alcohol.2004.08.002

Buege, J. A.; Aust, S. D., 1978. Microsomal lipid peroxidation. Methods in Enzymology. 52, 302-310. https://doi.org/10.1016/S00766879(78)52032-6

Chand, N.; Muhammad, D.; Durrani, F.; Subhan, Q. and Ullah, S., 2011. Protective Effects of Milk Thistle 
(Silybum Marianum) against Aflatoxin B1 in Broiler Chicks Asian-Aust. Journal of Animal Science, 24: 1011 1018.

Clarke, S. F.; Murphy, E. F.; Nilaweera, K.; Ross, P. R.; Shanahan, F.; O'Toole, P. W.; Cotter, P. D., 2012. The gut microbiota and its relationship to diet and obesity: New insights. Gut Microbes, 1; 3(3): 186-202. doi: 10.4161/gmic. 20168

Davis, C. D., 2017. The Gut Microbiome and Its Role in Obesity.J. Nutr. Today, 51(4): 167-174. doi: 10.1097/NT.0000000000000167.

De-Man, J. C.; Rogosa, M. and Sharpe, M. E.,1960. "A Medium for the Cultivation of Lactobacilli". J. Appl. Bact., 23:130-135. doi:10.1111/j.13652672.1960.tb00188.x.

Dixit, N.; Baboota, S.; Kohli, K.; Ahmad, S. and Ali, J., 2007. Silymarin: A review of Pharmalogical aspects and bioavilability enhancement approches. Indian J. Pharamacol, 39:172-196.

Doumas, B.T.; Bayso, D. D.; Carter, R. J.; Peter, T. and Schaffer, R., 1981. Determination of serum albumin. Clin. Chem., 27 (10):1642- 1650.

Draz, E. I.; Abdin, A. A.; Sarhan, N. I.; Gabr, T. A., 2015. Neurotrophic and antioxidant effects of silymarin comparable to 4-methylcatechol in protection against gentamicininduced ototoxicity in guinea pigs. Pharmacological Reports, 67 (2): 317325.

https://doi.org/10.1016/j.pharep.2014.10 .007

Duncan, D.B. 1955. Multiple range and multiple F tests. Biometrics, 11: 1-42.

El-Far, M.; El-Motwally A. G.; Hashem, I. A. and Bakry, N., 2009a. Biochemical role of intravaginal sildenafil citrate as a novel antiabortive agent inunexplained recurrent spontaneous miscarriage: first clinical study of four case reports from
Egypt.Clin. Chem. Lab.

Med.,47(11):1433-1438.

El-Far, M.; El-Sayed, I. H.; El-Motwally, A. E.; Hashem, I. A. and Bakry, N.,2009b. Serum levels of TNF-alpha and antioxidant enzymes and placentalTNF-alpha expression in unexplained recurrent spontaneous miscarriage.J. Physiol. Biochem., 65(2): 175-181.

El-Far, M.; Salah, N.; Essam, A.; Abd El-Azim, A. O. and El-Sherbiny, I. M., 2018. Silymarin nanoformulation as potentialanticancer agent in experimental Ehrlichascites carcinomabearing animals. Nanomedicine (Lond), 13(15):1865-1888.

El-Gazayerly, O. N.; Makhlouf, A. I.; Soelm, A. M. and Mohmoud, M. A.,2014. Antioxidant and hepatoprotective effects of silymarin phytosoes compared to milk thistle extract in $\mathrm{CCl} 4$ induced hepatotoxicity in rats. J. Microencapsul, 31(1):23-30.

El-Said, E. A., 2017. Effect of Fortification of Eggs with Folic acid During Incubation and Post Hatch Ascorbic Acid Addition on Productive Performance, Blood Constituents and Immune Status of Broiler Chicks.Egyptian J. Nutrition and Feeds; 20 (2): 279-287.

Ershidat, O. T. M., 2017. Dietary supplementation with the natural carotenoids curcumin and/or milk thistle seed improved the rats' liver and kidney functions and structure. International Journal of Food Science and Nutrition, 2, (1):169-173.

Esmaeil, N.; AnarakiMarjan, S. B;Marjan, G. and Moayedi, G. B., 2017. Silymarin impacts on immune system as an immunomodulator: One key for many locks. International immunopharmacology, 50:194-201. DOI: 10.1016/j.intimp.2017.06.030

Fanoudi, S.; Alavi, M. S.; Karimi, G.and Hosseinzadeh, H.,2020. Milk thistle (Silybum Marianum) as an antidote or a 
protective agent against natural or chemical toxicities: a review, Drug and Chemical Toxicology, 43:(3):240-254, DOI: $10.1080 / 01480545.2018 .1485687$

Fehér, J.; Láng, I.; Nékám, K.; Müzes, G. and Deák, G.,1988. Effect of free radical scavengers on superoxide dismutase (SOD) enzyme in patients with alcoholic cirrhosis. Acta Med Hung., 45:265-276.

Fossati, P. and Prencipe, L., 1982."Serum triglycerides determined colorimetrically with an enzyme that produces hydrogen peroxide." Clinical chemistry, 28, (10): 2077-80.

Fraschini, F.; Demartini, G and Esposti, D., 2002. Pharmacology of Silymarin. Clin Drug Invest, 22 (1): 51-65. 1173$2563 / 02 / 0001-0051 / \$ 22.00 / 0$

Friedewald, W. T.; Levy, R. I. and Fredrickson, D. S., 1972. Estimation of the concentration of low-density lipoprotein cholesterol in plasma, without use of the preparative ultracentrifuge. Clin. Chem., 18: 499-502.

Karimi, G.; Vahabzadeh, M.; Lari, P.; Rashedinia, M. and Moshiri, M., 2011. Silymarin", a Promising Pharmacological Agent for Treatment of Diseases. Iran J. Basic Med. Sci., 14(4): 308-317.

Gowda, S. K. and Sastry, V. R. B., 2000. Neem (Azadirachta indica) seed cake in animal feeding-scope and limitationReview. Asian Australasian J. of Ani. Sci., 13: 720-728.

Grant, G. H.; Silverman, L. M. and Christenson, R. H. 3th Ed. WB Saunders Company; Philadelphia: 1987. Aminoacids and proteins. (Fundamental of Clinical Chemistry).

Grizzle, J.; Wiles, J. and Benyard, R., 2003. In Vitro screening of nutriceuticals for immunosupport in avian. Annual Reports, Department of Animal Science, Institute of Agriculture, the University of Tenessee, USA.

Gupta, O. P.; Sing, S.; Bani, S.; Sharma, N.; Malhotra, S.; Gupta, B. D.;
Banerjee, S. K. and Handa, S. S., 2000. Anti-inflammatory and antiarthritic activities of silymarin acting through inhibition of 5- lipoxygenase. Phyto Med., 7:21-24. https://doi.org/10.1016/S09447113(00)80017-3

Henry, T. J. $2^{\text {nd }}$ Ed., 1974. Harper and Row Publishers; New York. Clinical Chemistry Principles and Techniques.

Huseini, H. F.; Larijani, B.; Heshmat, R.; Radjabipour, B.; Toliat, T. and Raza, M., 2006. The efficacy of Silybum marianum Gaertn. in the treatment of type IIdiabetes: A randomized double-blind placebo controlled clinical trial. Phytother Res., 20:1036-1039.

Jose, M. A.; Abraham, A. and Narmadha, M. P., 2011. Effect of silymarin in diabetes mellitus patients with liver diseases. J Pharmacol Pharmacother, 2:287-289.

Kalorey, D. R.; Kurkure, N. V.; Ramgaonkar, I. S.; Sakhare, P. S.; Warke, S. and Nigot, N. K., 2005. Effect of polyherbalfeed supplement "Growell" during induced aflatoxicosis, ochratoxicosis and combined mycotoxicoses in broilers. AsianAustralian Journal of Animal Science, 18:375-383.

Karimi, G.; Vahabzadeh, M.; Lari, P.; Rashedinia, M. and Moshiri, M., 2011. "Silymarin", a promising pharmacological agent for treatment of diseases. Iranian journal of basic medical sciences, 14(4), 308-317.

Kaur, G.; Athar, M. and Alam, M. S., 2010. Dietary supplementation of silymarin protects against chemically induced nephrotoxicity, inflammation and renal tumor promotion response. Invest New Drugs, 28:703-713.

Khazim, K.; Gorin, Y.; Cavaglieri, R. C.; Abboud, H. E. and Fanti, P., 2013. The antioxidant silybin prevents high glucose-induced oxidative stress and podocyte injury in vitro and in vivo. 
American Journal of Physiology-Renal Physiology, 305(5):691-700. doi: 10.1152/ajprenal.00028.2013.

Kind, P. R. and King, E. G., 1954. Colorimetric determination of alkaline phosphatase activity. J. Clin. Pathol.,7:322.

Kiruthiga, P. V.; Shafreen, R. B.; Pandian, S. K. and Devi, K. P., 2007. Silymarin protection against major reactive oxygen species released by environmental toxins: exogenous $\mathrm{H}_{2} \mathrm{O}_{2}$ exposure in erythrocytes. Basic \& Clinical Pharmacology \& Toxicology, 100(6):414-419. doi: 10.1111/j.17427843.2007.00069.x.

Koracevic, D.; Koracevic, G.; Djordjevic, V.; Andrejevic, S. and Cosic, V., 2001. Method for the measurement of antioxidantactivity in human fluids. J. Clin. Pathol.,54: 356-361.

Krečman, V.; Škottová, N.; Walterová, D.; Ulrichová, J. and Šimánek, V., 1998. Silymarin inhibits the development of diet-induced hypercholesterolemia in rats. Planta Med., 64:138-142.

Kshirsagar, M.; Mahash, V.; Srinivas, P.; and Mangala, L., 2013. Evaluation of the protective effect of silymarin on doxorubicin induced chronic testicular toxicity in Rats. International Journal of Pharmacy and Biological Sciences, 4: $473-484$.

Kshirsagar, M.; Mahash, V.; Srinivas, P.; and Mangala, L., 2013. Evaluation of the protective effect of silymarin on doxorubicin induced chronic testicular toxicity in Rats. International Journal of Pharmacy and Biological Sciences, 4: $473-484$.

Kummer, V.; Mašková, J.; Čanderle, J.; Zralý, Z.; Neča, J. and Machala, M., 2001. Estrogenic effects of silymarin in ovariectomized rats.Vet. Med. Czech46(1): 17-23.

Lahlah, Z. F.; Meziani, M. and Maza, A.,2012. Silymarin Natural Antimicrobiol Agent Extracted from Silybum marianum. J. Acad.2: 164-169.
Lee, D. G.; Kim, H. K.; Park, Y.; Park, S. C.; Woo, E. R.; Jeong, H. G. and Hahm, K. S.,2003. Gram Positive bacteria specific properties of silybin derived from Silybum marianum. Arch. Pharm. Res., 26: 597-600.

Lee, T. Y.; Mai, L. M.; Wang, G. J.; Chiu, G. H.; Lin, Y. L.; Lin, H. C., 2003. Protective mechanism of salvia miltiorrhiza on carbon tetrachloride-induced acute hepatotoxicity in rats. Journal of Pharmacological Sci., 91 (3):202-210. https://doi.org/10.1254/S13478613(19)32735-5.

Lopez-Virella, M. F.; Stone, P.; Ellis, S. and Colwell, J. A., 1977. Cholesterol determination in high-density lipoproteins separated by three different methods. Clin. Chem. 23, (5) 882-884.

Lucena, M. I.; Andrade, R. J.;De la Cruz, J. P.; Rodriguez-Mendizabal, M.; Blanco, E.;De la Cuesta, F. S., 2002. Effects of silymarin MZ-80 on oxidative stress in patients with alcoholic cirrhosis. Results of a randomized, double-blind, placebocontrolled. International Journal of Clinical Pharmacology and Therapeutics, 40 (1), 2-8.DOI: $10.5414 / \mathrm{cpp} 40002$

Lutsenko, S.; Kashnikova, T.; Khmyrov, A.; Ledeshkova, O.; Fel'dman, N. and Luzhnov, N., 2008. Study of the effect of a liposomal form of silymarin on biochemical indices of the blood serum and productivity of broiler chicks. Russian Agricultural Sci., 34(6):415-7.

MacConkey, A. T., 1908. "Bile Salt Media and their advantages in some Bacteriological Examinations". J Hyg $\begin{array}{llll}\text { (Lond). } & 8 & \text { (3): } & 322-34 .\end{array}$ doi:10.1017/s0022172400003375.

Maghrani, M.; Zeggwagh, N. A.; Lemhadri, A.; Amraoui, M.; Michel, J. and Eddouks, M., 2004. Study of the hypoglycaemic activity of silymarin in an animal model of type 1 diabetes mellitus. J. Ethnopharmacol, 91:309-16

Manna, S. K.; Mukhopadhyay, A.; Van, N. T. and Aggarwal, B. B., 1999. Sily- 
silymarin, lipids, immunity, antioxidant, duck

marin suppresses TNF-induced activation of NF-kappa B, c-Jun Nterminal kinase, and apoptosis. J. Immuno., 1163: 6800-6809.

Marzal PC, Chumbimuni-Torres KY, Höehr NF, Kubota LT (2006) Determination of glutathione in hemolysed erythrocyte with amperometric sensor based on TTF-TCNQ. Clin Chim Acta 371:152-158

Misra, H. P.; and Fridovich, I., 1972. The role of superoxide anion in the autooxidation of epinephrine and simple assay for superoxide dismutase. J. Biol. Chem., 247:3170-3175.

Mojahedtalab, A. R.; Mohammadi, M.; Mehr, M. R. A. and Asadi, M., 2013. Effect of Silymarin on performance and immune responses of broilers. Animal Production Research, 2 (3):49-58.

Morishima, C.; Shuhart, M.C.; Wang, C.C.; Paschal, D.M.; Apodaca, M.C.; Liu, Y.; Sloan, D.D.; Graf, T.N.; Oberlies, N.H.; Lee, D.Y.W.; Jerome, K.R. and Polyak, S.J., 2010. Silymarin inhibits in vitro t-cell proliferation and cytokine production in hepatitis c virus infection. Gastroenterology 138: 671681.

Nazemian, F.; Karimi, G.; Moatamedi, M.; Charkazi, S.; Shamsara, J. and Mohammadpour, A. H., 2010. Effect of silymarin administration on TNFalpha serum concentration in peritoneal dialysis patients. Phytother Res., 24:1654-1657.

https://doi.org/10.1002/ptr.3175

Neshatgharamalek, M. and Mohajer, D., 2014. Study the protective effects of Black Cumin (Nigella sativa Lin.) ethanolic extract against Rifampininduced hepatotoxicity in rats. Qom. Univ. Med. Sci. J. 8:73-84.

Noorani, A. A.; Mulla, K. and Patil, S. D., 2010. Hepatoprotective effect of Cocculus Hirsutuslinn against ethanol induced liver damage in Wister rats. Pharmacophore, 1(2):82-89.

Par, A.; Róth, E.; Rumi, G. Jr.; Kovács, Z.; Nemes, J. and Mózsik, G., 2000.
Oxidative stress and antioxidant defense in alcoholic liver disease and chronic hepatitis C. Orvosi Hetilap, 141 (30): $1655-1659$.

Patton, C. J. and Crouch, S. R., 1977. Enzymatic determination of urea. Anal. Chem., 49:464-469.

Pradhan, S. C. and Girish C., 2006. Hepatoprotective herbal drug silymarin from experimental pharmacology to clinical medicine. Indian J. Med. Res., 124:491-504.

Radko, L. and Cybulski, W., 2007. Application of silymarin in human and animal medicine. Journal of Pre-Clinical and Clinical Research, 1: 22-26

Rajiha, A., 2012. The therapeutic effect of Silybum marianum on the lead acetate induced reproductive toxicity in both gender laboratory rats. Journal Sci. \& Medicine, 5(1):144-15.

Reitman, S. and Frankel, S., 1957. Colorimetric method for determination of serum transaminases activities. Am. J. Clin. Path., 28:56-68.

Robin, P. P. and Visser, T. J., Ph.D.2017. Metabolism of Thyroid Hormone. Endotext [Internet]. South Dartmouth (MA): MDText.com, Inc.; 2000-.2017 Jan 1 .

Saeed, M.;XU, Y.; Rehman, Z.U.; Arain, M.A.; Soomro, R.N.; Abd Elhack, M.E.; Bhutto, Z.A.; Abbasi, B.; Dhama, K.; Sarwar, M. and Chao, S., 2017b. Nutritional and Healthical Aspects of Yacon (Smallanthus sonchifolius) for Human, Animals and Poultry. International Journal of Pharmacology 13: 361-369.

Saeed, M.; Babazadeh, D.; Arif, M.; Arain, M. A.; Bhutto, Z. A.; Shar, A. H.; Kakar,M. U.; Manzoor, R. and Chao, S., 2017a. Silymarin: a potent hepatoprotective agent in poultry industry. World's Poultry Science Journal, 73:483- 492. doi:10.1017/S0043933917000538

Saller, R.; Meier, R. and Brignoli, R., 2001. The use of silymarin in the 
treatment of liver diseases. Drugs, 61:2035-2063.

SAS, 2006. Statistical Analysis System. SAS User's Guide: Statistics SAS institute Inc., Cary, NC, USA.

Shaker, E.;Mahmoud, H. and Mnaa, S., 2010. Silymarin, the antioxidant component and Silybum marianum extracts prevent liver damage. Food and Chemical Toxicology, 48: 803-806.

Simanek, V.; Kren, V.; Ulrihova, J.; Vicar, J. and Cvak, L., 2000. New application of Silybin and Silynarin. Hepatology, 32: 442.

Škottová, N.; Krečman, V. and Šimánek, V., 1999. Activities of silymarin and its flavonolignans upon low density lipoprotein oxidizability in vitro. Phytother Res., 13:535-537.

Soto, C.; Mena, R.; Luna, J.; Cerbon, M.; Larrieta, E.; Vital, P.; Uria, E.; Sanchez, M.; Recoba, R. and Barron, H., 2004. Silymarin induces recovery of pancreatic function after alloxan damage in rats. Life Sci. 75:2167-2180.

Soto, C.; Recoba, R.; Barron, H.; Alvarez, C. and Favari, L., 2003. Silymarin increases antioxidant enzymes in alloxaninduced diabetes in rat pancreas. Comparative biochemistry and physiology part C. Comp Biochem Physiol C Toxicol Pharmacol. 136:205212.

Stein, E. A., 1986. In " Textbook of Clinical Chemistry " NW Tiez \& WB saunder Eds., Philadelphia, pp. 879886, 1818-1829.

Sturkie, P. D. (Ed.), 1986. Avian Physiology, Springer-Verlag, New York, NY., pp. 103-121

Surai, P.F., 2015.Silymarin as a natural antioxidant: an overview of the current evidence and perspectives. Antioxidants 4: 204-247.

Talebi1, A.; Sadaghiani, A. H. and Zare, P., 2015. Effects of Silymarin on blood parameters of broilers in an experimental chronic mycotoxicosis.
Journal of Mycology Research, 2, (1): 31-39.

Tan, J.; Hu, J.; He, Y. and Cui, F., 2015. Protective role of silymarin in a mousemodel of renal ischemiareperfusion injury. Diagnostic Pathology 10: 1-16.

Tedesco, D.; Domeneghini, C.; Sciannimanico, D.; Tameni, M.; Steidler, S. and Galletti, S., 2004. Efficacy of silymarin phospholipid complex in reducing the toxicity of aflatoxin B1 in broiler chicks. Poultry Science, 83: 1839-1843.

Trinder, P. (1969). Determination of blood glucose using an oxidase-peroxidase system with a non-carcinogenic chromogen. J. Clin. Pathol. 22(2):158161. doi: 10.1136/jcp.22.2.158.

Upadhyay, G.; Tiwari, M.N.;Prakash, O.;Jyoti, A.;Shanker, R. and Singh, M. P., 2010. Involvement of multiple molecular events in pyrogallol-induced hepatotoxicity and silymarin-mediated protection: Evidence from gene expression profiles. Food and Chemical Toxicology 48: 1660-1670.

Walker, W. H. C.,1977. Introduction: An Approach to Immunoassay", Clin. Chem., 23(2): 384.

Ward, F. M. and Daly, M. J., 2003. Liver disease. In: Roger W, Clive E, editors. Clinical pharmacy and therapeutics. 3rd ed. Edinburgh: Churchill Livingstone, p. 209-225.

Wellington, K. and Jarvis, B., 2001. Silymarin: a review of its clinical properties in the management of hepatic disorders. Bio. Drugs, 15(7):465-89.

Wilasrusmee, C.; Kittur, S.; Shah, G.; $\quad$ Siddiqui, J.; $\quad$ Bruch, D.; Wilasrusmee, S.; Kittur, D. S.,2002. Immunostimulatory effect of Silybum Marianum (milk thistle) extract. Med. Sci. Monit., 8(11):439-43.

Windisch, W.; Schedle, K.; Plitzner, C.; Kroismayr, A., 2008. Use of phytogenic products as feed additives for swine and poultry, Journal of Animal 
Sci.,86:140-148.

https://doi.org/10.2527/jas.2007-0459.

Wisdom, G. B., 1976. Enzymeimmunoassay. Clin. Chem. 22, 12431255.

Wu, J. W.; Lin, L. C.; and Tsai, T. H., $2009 . \quad$ Drug-druginteractionsof silymarinontheperspectiveof pharmacokinetics.J.Ethnopharmacol Ethno Pharm., 121:181-193.

Zhao, F.; Shi, D.; Li, T.; Li, L. and Zhao, M., 2015.Silymarin attenuates paraquatinduced lung injury via Nrf2mediated pathway in vivo and in vitro. Clinical and Experimental Pharmacology and Physiology 42: 988998.

Zhenga, X.; Wanga, X.; Lanb, Y.; Shic, J.; Xuec, S. J. and Liua, C., 2009. Application of response surface methodology to optimize microwaveassisted extraction of silymarin from milk thistle seeds. Separation and Purification Technology, 70:34-40.

\section{تأثير مستخلص السليمارين على الاستجابات الفسيولوجية و المناعية لسلالة البط الفرنساوى (Cairina Moschata Domestica)

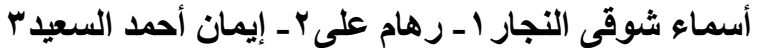

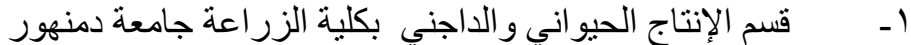

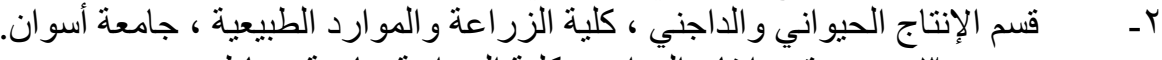

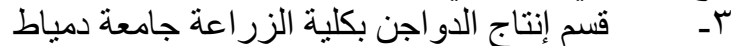

أجريت هذه الدر اسة لمعرفة نأثير مستخلص السيليمارين على الأداء الإنتاجي و الحالة المناعية والفسيولوجية لسية لسلالة البط

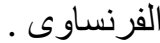

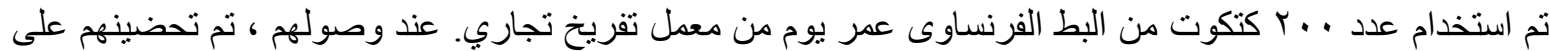

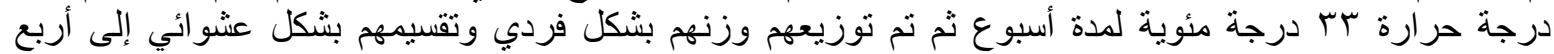

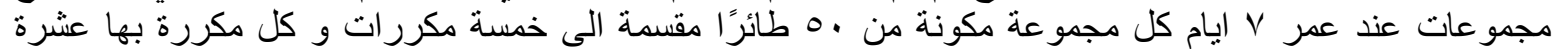

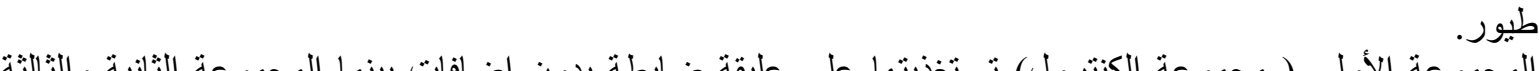
المجمو عة الأولى ( مجموعة الكنترول) نم تغذيتها على عليقة ضابطة بدون اضافات بينما المجموعة الثانية و الثالثة

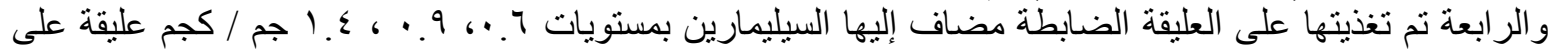

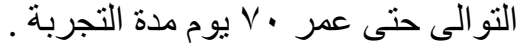

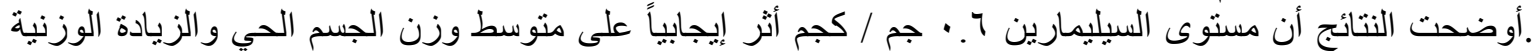

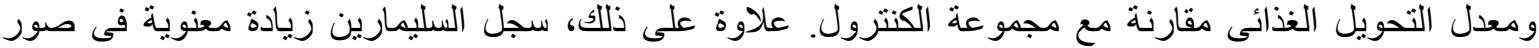

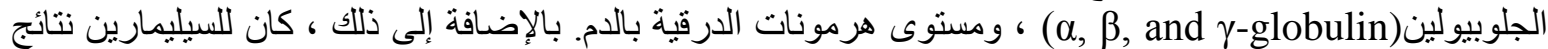

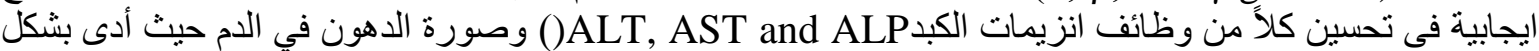

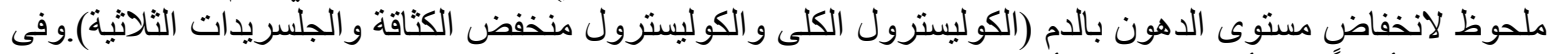

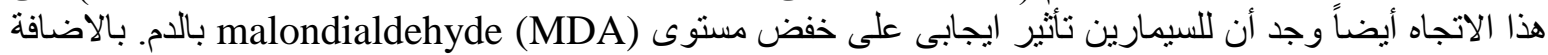
إلى تحسن مستوى مضادات الأكسدة و الاستجابات المناعية وتثبيط نمو بكتريا القولون فى معاملات السليمارين مقارنة بلإنة

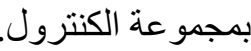

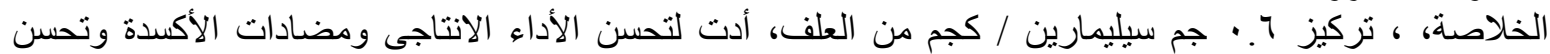

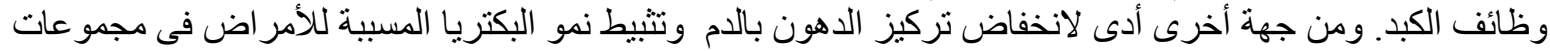
البط المعاملة بالسليمارين مقارنة بمجمو عة الكنترول. 